Authors' Contribution:

A Study Design

B Data Collection

C Statistical Analysis

D Data Interpretation

E Manuscript Preparation

F Literature Search

G Funds Collection

\section{BMI of students of School of Sport - facts and self-assessment in the context of physical activity and parents' education. Long-standing research}

\author{
Ewa Wójtowicz ABCDEFg, Barbara Duda-Biernacka DeF \\ Department of Anatomy and Anthropology, Chair of Natural Science, Gdansk University \\ of Physical Education and Sport in Gdansk, Poland
}

abstract

Background

Material/Methods

Results

Conclusions

Key words

\section{article details}

Article statistics

Full-text PDF:

Copyright

Indexation:

Funding:

Conflict of interest: Corresponding author:

Open Access License:
The objective of this study is self-recorded BMI among 20-year-old female students in the context of their physical activity, weight, body height, parent's education and the time factor.

Statistical analysis of the data was based on anthropometric measurements and a survey conducted among female students ( $N=1,394)$ from the first year of full-time studies at the Gdansk University of Physical Education and Sport (AWFiS) in the years 2003-2010. The relationship between variables and logistic models was analyzed (Student's test, Duncan's test, analysis of variance, logistic regression). Statistical analysis was conducted using Statistica 6.0 software.

At the background of the research results it may be claimed that incorrect self-reported BMI favors sport $(O R=0.71)$, father's elementary or basic vocational education $(O R=1.44)$, higher weight $(O R=0.90)$ and $B M I(O R=0.76)$ and lower height $(O R=1.07) .29 .77 \%$ women did not evaluate their BMI correctly during the whole 8-year research process. The correct BMI was reported by $70.23 \%$ of the students; $26.76 \%$ overestimated their $\mathrm{BMI}$ and $3.01 \%$ underestimated it. A high percentage of women who practice sport and who incorrectly determined their own BMI (31.25\%) is disquieting, including $8.82 \%$ of the students who underestimated their BMI, and $91.18 \%$ who overestimated it.

Failure to correctly evaluate BMI may lead to nutrition disorders, low self-esteem and serious health consequences. It is reasonable to develop regular and skillful evaluation of $\mathrm{BMI}$ among young people by institutions and people involved in health promotion.

female students, BMI, self-assessment, physical activity, parents' education, long-standing research
Word count: 2,480; Tables: 4; Figures: 1; References: 17

Received: November 2016; Accepted: December 2016; Published: March 2017

http://www.balticsportscience.com

(c) Gdansk University of Physical Education and Sport, Poland

AGRO, Celdes, CNKI Scholar (China National Knowledge Infrastructure), CNPIEC, De Gruyter - IBR (International Bibliography of Reviews of Scholarly Literature in the Humanities and Social Sciences), De Gruyter - IBZ (International Bibliography of Periodical Literature in the Humanities and Social Sciences), DOAJ, EBSCO - Central \& Eastern European Academic Source, EBSCO - SPORTDiscus, EBSCO Discovery Service, Google Scholar, Index Copernicus, J-Gate, Naviga (Softweco, Primo Central (ExLibris), ProQuest - Family Health, ProQuest - Health \& Medical Complete, ProQuest - Illustrata: Health Sciences, ProQuest - Nursing \& Allied Health Source, Summon (Serials Solutions/ProQuest, TDOne (TDNet), Ulrich's Periodicals Directory/ulrichsweb, WorldCat (OCLC)

This research received no specific grant from any funding agency in the public, commercial, or not-for-profit sectors.

Authors have declared that no competing interest exists.

Dr. Ewa Wójtowicz, Gdansk University of Physical Education and Sport in Gdansk, Chair of Natural Science, Department of Anatomy and Anthropology, ul. Kazimierza Górskiego 1, 80-336 Gdańsk, Poland; e-mail address: ewawoj14@wp.pl

This is an open access article distributed under the terms of the Creative Commons Attribution-Non-commercial 4.0 International (http://creativecommons.org/licenses/by-nc/4.0/), which permits use, distribution, and reproduction in any medium, provided the original work is properly cited, the use is non-commercial and is otherwise in compliance with the license. 


\section{INTRODUCTION}

Taking care of one's body, through body weight control and connected with it well-balanced diet, among other things, reduces a risk of many diseases $[1,2,3,4]$. There is a common belief that slim people have easier life. It is easier for them to find a partner, good job; they are happy, sexually attractive and, in consequence, more confident $[5,6,7,8]$. Obese people are seen as stereotypically lazy, slow and less confident, and by this emotionally unstable. Media have a special impact on the formation of these patterns. Anxiety, a sense of gap between the "ideal body" forged by mass media and one's own "real body", is often at the root of psychological and social problems (low self-esteem, social alienation, depression). How people imagine their own body and compatibility of this image with reality essentially affects human thinking, experience and activity [6, 9, 10]. Wrong BMI evaluation tends to cause irresponsible eating habits, which can result in serious health problems.

The objectives of the study included:

- learning the skill of correct BMI self-assessment by female students of Gdansk University of Physical Education and Sport (AWFiS) and comparing it with anthropometric measurements;

- assessing the likelihood of correct self-assessment in the context of young women's physical activity, height and weight, as well as the level of their parents' education and the time factor.

\section{MATERIAL AND METHODS}

Statistical analysis of the data was based on anthropometric measurements and a survey conducted among female students $(\mathrm{N}=1.395)$ from the first year of full-time studies at Gdansk University of Physical Education and Sport (AWFiS) in the years 2003-2010. The examined students were healthy, fit and physically active women at the turn of adolescence and adulthood. The mean age of the sample was 20.28 years. The average value of body weight was 60.61 $\mathrm{kg}$, body height $167.61 \mathrm{~cm}$, and BMI $21.55 \mathrm{~kg} / \mathrm{m}^{2}$. The level of the subjects' physical activity varied a lot. $34.58 \%$ of the students had participated in extra activities (beyond the curriculum, for at least 1 year under supervision of a coach), whereas $21.95 \%$ of students had never participated in such classes and $43.47 \%$ of them had been active some time ago but not during the study period. Some of the respondents refused to give their consent to use the information for research purposes, which had an impact on the number of observations during different stages of analyses.

Anthropometric measurements were performed each year in the same period by the same person. Before proceeding to the anthropometric measurements, the tested students filled in a questionnaire which asked them, among others, about the most satisfying for them BMI category (underweight, normal weight, overweight, obesity, extreme obesity). Measurements of the body weight and the body height were performed in accordance with the rules with a use of medical scales (body weight) and an anthropometer (body height). The value of the proper body mass was defined using the Body Mass Index (BMI):

$$
\mathrm{BMI}=\text { body mass }[\mathrm{kg}]:(\mathrm{B}-\mathrm{v})^{2}[\mathrm{~m}] .
$$


The following ranges of BMI values were considered [11]:

BMI $<18.5 \mathrm{~kg} / \mathrm{m}^{2}$ - underweight,

$18.5 \mathrm{~kg} / \mathrm{m}^{2} \leq \mathrm{BMI}<25.0 \mathrm{~kg} / \mathrm{m}^{2}$ - normal weight,

$25.0 \mathrm{~kg} / \mathrm{m}^{2} \leq \mathrm{BMI}<30.0 \mathrm{~kg} / \mathrm{m}^{2}$ - overweight,

$30.0 \mathrm{~kg} / \mathrm{m}^{2} \leq \mathrm{BMI}<40.0 \mathrm{~kg} / \mathrm{m}^{2}$ - obesity,

$40.0 \mathrm{~kg} / \mathrm{m}^{2} \leq \mathrm{BMI}-$ extreme obesity.

Statistical analysis of the results was conducted using Statistica 6.0 software. Logistic regression, non-parametric chi-square test, analysis of variance, t-test for independent samples, Duncan's test, and units odds ratio (OR) were used for the study. The following variables and their categories were analyzed in the study:

independent variables $\left(\mathrm{x}_{1}-\mathrm{x}_{7}\right)$

$\mathrm{x}_{1}$ - year of study $(3=2003,4=2004,5=2005,6=2006,7=2007,8=$ $2008,9=2009,10=2010$ ),

$\mathrm{x}_{2}$ - physical activity $(0=$ students who never participated in regular extra sports classes with a coach, beyond curriculum, for minimum 1 year, $1=$ students who had participated in the past or at the time of the study in regular extra sports classes with a coach, beyond curriculum, for minimum 1 year),

$\mathrm{x}_{3}$ - mother's educational background $(0=$ primary or vocational, $1=$ high or university),

$\mathrm{x}_{4}$ - father's educational background $(0=$ primary or vocational, $1=$ high or university),

$\mathrm{x}_{5}$ - body weight $[\mathrm{kg}]$ (anthropometric measurements),

$\mathrm{x}_{6}$ - body height $[\mathrm{cm}]$ (anthropometric measurements),

$\mathrm{x}_{7}$ - BMI $\left[\mathrm{kg} / \mathrm{m}^{2}\right]$ (calculated on the basis of anthropometric measurements).

dependent variable (Y)

$\mathrm{Y}$ - probability of self-reported BMI in comparison with real life, i.e. BMI calculated on the basis of anthropometric measurements: $(0=$ self-reported BMI inconsistent with reality, 1 = self-reported BMI in line with reality).

\section{RESULTS}

Correct self-reported BMI was made by $70.23 \%$ of the students, $26.76 \%$ overestimated the results and 3.01\% underestimated the values. Students who calculated BMI in line with reality have significantly lower body weight and BMI than those students who decreased or increased their values; however, body height has similar values for all students (Tables 1 and 2). A lack of significant differences in the mean values of body weight, height and BMI in students over or underestimating their BMI was observed (Tables 1 and 2). 
Table 1. AWFiS female students self-assessing BMI - mean values of BMI, body weight and height determined on the basis of anthropometric measurements

\begin{tabular}{|c|c|c|c|c|c|c|}
\hline \multirow[b]{2}{*}{$\begin{array}{l}\text { Self-recorded BMI compared with the calculated } \\
\text { BMI on the basis of anthropometric measurements: }\end{array}$} & \multicolumn{2}{|c|}{$\begin{array}{l}\text { Body weight } \\
{[\mathrm{kg}]}\end{array}$} & \multicolumn{2}{|c|}{$\begin{array}{l}\text { Body height } \\
{[\mathrm{cm}]}\end{array}$} & \multicolumn{2}{|c|}{$\mathrm{BMI}\left[\mathrm{kg} / \mathrm{m}^{2}\right]$} \\
\hline & M & SD & M & SD & M & SD \\
\hline Consistent (a) & 59.53 & 7.04 & 167.58 & 6.199 & 21.17 & 1.98 \\
\hline Inconsistent (b) & 63.16 & 8.26 & 167.69 & 6.46 & 22.42 & 2.30 \\
\hline The significance of differences between $a$ and $b$ & \multicolumn{2}{|c|}{$\begin{aligned} t & =-8.34 \\
p & =0.000000\end{aligned}$} & \multicolumn{2}{|c|}{$\begin{array}{c}t=-0.30 \\
p=0.8\end{array}$} & \multicolumn{2}{|c|}{$\begin{aligned} t & =10.26 \\
p & =0.000000\end{aligned}$} \\
\hline Overstated (c) & 63.13 & 7.36 & 167.70 & 6.54 & 22.41 & 1.86 \\
\hline Undervalued (d) & 63.42 & 14.08 & 167.55 & 5.79 & 22.56 & 4.70 \\
\hline The significance of differences between $a, c$ and $d$ & \multicolumn{2}{|c|}{$\begin{array}{c}F=34.81 \\
P=0.000000\end{array}$} & \multicolumn{2}{|c|}{$\begin{array}{l}F=0.06 \\
P=0.9\end{array}$} & \multicolumn{2}{|c|}{$\begin{array}{c}F=52.74 \\
P=0.000000\end{array}$} \\
\hline
\end{tabular}

$\mathrm{t}$ - test $\mathrm{t}$ for independent samples, $\mathrm{F}$ - statistics $\mathrm{F}, \mathrm{p}$ - level of statistical significance

Table 2. The significance of differences between mean values of weight, height and BMI of students properly evaluating it (a), overestimating values (c) and underestimating values (d) of their self BMI - Duncan's test

\begin{tabular}{|c|c|c|c|c|c|c|c|c|c|c|}
\hline \multicolumn{4}{|c|}{ Body weight } & \multicolumn{3}{|c|}{ Body height } & \multicolumn{4}{|c|}{ BMI } \\
\hline & $a$ & C & $d$ & & C & $d$ & & $a$ & C & $d$ \\
\hline a & & $*$ & $*$ & a & & & a & & $*$ & $*$ \\
\hline C & $*$ & & & C & & & c & $*$ & & \\
\hline$d$ & $*$ & & & $d$ & & & $d$ & $*$ & & \\
\hline
\end{tabular}

There was a significant relationship between self-reported BMI compatible and incompatible with reality and the year of research, physical activity and father's education. There is no such relationship in case of mother's education (Table 3).

Table 3. Self-recorded BMI made by the students taking into account the category of qualitative independent variables

\begin{tabular}{|c|c|c|c|c|c|c|c|c|}
\hline \multirow{3}{*}{ Independent variables } & \multicolumn{8}{|c|}{$\begin{array}{l}\text { Self-recorded BMI compared with the calculated } \\
\text { BMI on the basis of anthropometric measurements }\end{array}$} \\
\hline & \multicolumn{2}{|c|}{ Consistent } & \multicolumn{2}{|c|}{ Inconsistent } & \multicolumn{2}{|c|}{ Undervalued } & \multicolumn{2}{|c|}{ Overstated } \\
\hline & $\mathrm{N}$ & $\%$ & $\mathrm{~N}$ & $\%$ & $\mathrm{~N}$ & $\%$ & $\mathrm{~N}$ & $\%$ \\
\hline Year of study $\left(x_{1}\right)$ & & $\chi^{2}=15.698$ & $p=0.03$ & & & $\chi^{2}=9.05$ & $p=0.3$ & \\
\hline 2003 & 195 & 71.43 & 78 & 28.57 & 9 & 3.30 & 69 & 25.27 \\
\hline 2004 & 113 & 63.84 & 64 & 36.16 & 3 & 1.69 & 61 & 34.46 \\
\hline 2005 & 97 & 60.25 & 64 & 39.75 & 3 & 1.86 & 61 & 37.89 \\
\hline 2006 & 103 & 73.05 & 38 & 26.95 & 3 & 2.13 & 35 & 24.82 \\
\hline 2007 & 100 & 75.76 & 32 & 24.24 & 3 & 2.27 & 29 & 21.97 \\
\hline 2008 & 142 & 74.35 & 49 & 25.65 & 6 & 3.14 & 43 & 22.51 \\
\hline 2009 & 120 & 71.86 & 47 & 28.14 & 8 & 4.79 & 39 & 23.35 \\
\hline 2010 & 109 & 71.71 & 43 & 28.29 & 7 & 4.61 & 36 & 23.68 \\
\hline Physical activity $\left(\mathrm{x}_{2}\right)$ & & $\chi^{2}=5.19$ & $p=0.02$ & & & $\chi^{2}=3.48$ & $p=0.06$ & \\
\hline $\begin{array}{l}\text { students who never participated in regular } \\
\text { extra sports classes with a coach, beyond } \\
\text { curriculum, for minimum } 1 \text { year }\end{array}$ & 231 & 75.49 & 75 & 24.51 & 12 & 16.00 & 63 & 84.00 \\
\hline $\begin{array}{l}\text { students who participated in the past or at } \\
\text { the time of the study in regular extra sports } \\
\text { classes with a coach, beyond curriculum, } \\
\text { for minimum } 1 \text { year }\end{array}$ & 748 & 68.75 & 340 & 31.25 & 30 & 8.82 & 310 & 91.18 \\
\hline Mother's educational background $\left(x_{3}\right)$ & & $\chi^{2}=0.03$ & $p=0.9$ & & & $\chi^{2}=0.06$ & $p=0.8$ & \\
\hline primary or vocational & 107 & 70.86 & 44 & 29.14 & 4 & 9.09 & 40 & 90.91 \\
\hline high or university & 869 & 70.14 & 370 & 29.86 & 38 & 10.27 & 332 & 89.73 \\
\hline Father's educational background $\left(x_{4}\right)$ & & $\chi^{2}=4.45$ & $p=0.03$ & & & $\chi^{2}=0.02$ & $p=0.9$ & \\
\hline primary or vocational & 201 & 65.47 & 106 & 34.53 & 11 & 10.38 & 95 & 89.62 \\
\hline high or university & 768 & 71.71 & 303 & 28.29 & 30 & 9.90 & 273 & 90.10 \\
\hline
\end{tabular}

$\mathrm{x}_{1}-\mathrm{x}_{4}$ - independent variables and their categories are described in the Material and methods section

Incorrect self-reported BMI was more frequently presented by students who practice or practiced sport regularly with a coach and in extra classes beyond the curriculum than by those who had never participated in such classes. Fathers' elementary or basic vocational education is also connected with more 
frequent incorrect calculations of BMI made by their daughters (Table 3).

There were no statistically significant relationships between over and underestimated BMI values and the qualitative variables; although a slightly higher percentage of women overestimating their BMI in 2003-2005 with a downward trend in subsequent years was observed. It was also found that students who took or take extra sports classes more often $(7.18 \%)$ had higher self-recorded BMI values than completely non-active students (Tab. 3). Worrying is a high percentage of students athletes whose self-recorded BMI is incorrect (31.25\%). Overestimation (91.18\% of wrong BMI self-assessment) seems to be a common phenomenon, while only $8.82 \%$ of the self-recorded BMI was underestimated.

After the estimation using Rosenbrock and quasi-Newton methods, a model of logistic regression was obtained, for which the value of the difference between the model composed of 6 independent variables $\left(\mathrm{x}_{1}-\mathrm{x}_{6}\right)$ and the model with an absolute term is only significant. However, parameters for variables $\mathrm{x}_{2}$ and $\mathrm{x}_{3}$ are not statistically significant. Interaction between $\mathrm{x}_{1}-\mathrm{x}_{7}$ variable force to create 3 separate models allowing an evaluation of the probability of correct BMI self-assessment. They all substantially differ from a model with only the absolute term, and parameters for each considered variable are statistically significant (Tab. 4). Such created models take the form of:

Logit $P=-5.61999+0.068915 x_{1}+0.363246 x_{4}-0.10093 x_{5}+0.07135 x_{6}$

Logit $\mathrm{P}=1.12493-0.33647 \mathrm{x}_{2}$

Logit $\mathrm{P}=6.829-0.27455 \mathrm{x}_{7}$

Table 4. Independent variables $\mathrm{x}_{1}, \mathrm{x}_{2}, \mathrm{x}_{4}, \mathrm{x}_{5}, \mathrm{x}_{6}, \mathrm{x}_{7}$ and the probability of correct BMI self-assessment by the students - logistic regression

\begin{tabular}{|c|c|c|c|c|c|c|c|}
\hline $\begin{array}{l}\text { Variable/ } \\
\text { constant }\end{array}$ & Assessment & Standard error & Wald $\mathrm{Chi}^{2}$ & $p$ & OR & $-95 \% \mathrm{~L}$ & $+95 \% \mathrm{~L}$ \\
\hline \multicolumn{5}{|c|}{ The probability of making a correct BMI self-assessment } & $\mathrm{Chi}^{2}=109.60$ & $p=0.0000$ & \\
\hline Constant & -5.61999 & 1.78470 & 9.91607 & 0.002 & 0.00362 & 0.00011 & 0.12016 \\
\hline $\mathrm{x}_{1}$ & 0.068915 & 0.025860 & 7.101940 & 0.008 & 1.071346 & 1.018353 & 1.127096 \\
\hline$x_{4}$ & 0.363246 & 0.143976 & 6.365386 & 0.01 & 1.437990 & 1.084165 & 1.907288 \\
\hline$x_{5}^{4}$ & -0.10093 & 0.01063 & 90.08878 & 0.00000 & 0.90400 & 0.88534 & 0.92305 \\
\hline$x_{6}^{3}$ & 0.07135 & 0.011252 & 32.44852 & 0.00000 & 1.07395 & 1.04789 & 1.10067 \\
\hline \multicolumn{5}{|c|}{ The probability of making a correct BMI self-assessment } & $\mathrm{Chi}^{2}=5.3341$ & \multicolumn{2}{|l|}{$p=0.02$} \\
\hline Constant & 1.12493 & 0.13282 & 71.73387 & 0.00000 & 3.08000 & 2.37354 & 3.99674 \\
\hline $\mathrm{x}_{2}$ & -0.33647 & 0.14801 & 5.16795 & 0.02 & 0.71429 & 0.53429 & 0.95492 \\
\hline \multicolumn{4}{|c|}{ The probability of making a correct BMI self-assessment } & \multicolumn{2}{|r|}{$\mathrm{Chi}^{2}=97.168$} & $p=0.0000$ & \\
\hline Constant & 6.829 & 0.649 & 110.670 & 0.00000 & 924.013 & 258.622 & 3301.344 \\
\hline $\mathrm{x}_{7}$ & -0.27455 & 0.02952 & 86.48582 & 0.00000 & 0.75991 & 0.71715 & 0.80522 \\
\hline
\end{tabular}




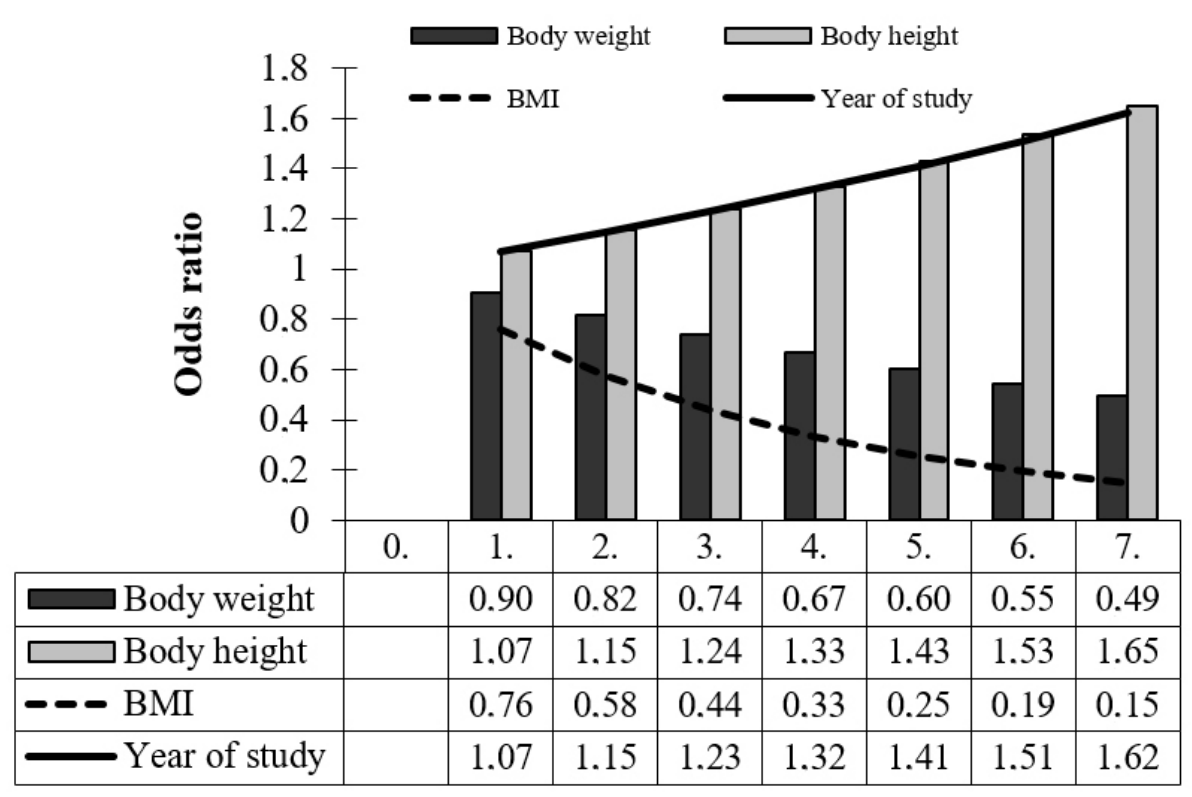

Fig. 1. Probability of compatible with the reality self-recorded BMI made by the students (body weight, body height, BMI, year of study)

Incorrect BMI self-assessment is fostered by: father's education below the secondary level $(\mathrm{OR}=1.496)$, practicing sport $(\mathrm{OR}=0.717)$, higher body weight $(\mathrm{OR}=0.904)$ and $\mathrm{BMI}(\mathrm{OR}=0.7599)$, and lower height $(\mathrm{OR}=1.704)$. In each subsequent year the subjects were characterized by a higher probability of correct self-recorded BMI (OR = 1.071) (Table 4, Fig. 1).

\section{DISCUSSION}

Dissatisfaction with the actual body build often leads to health (subjective evaluation of one's own appetite as too big), psychological and social (low self-esteem, social isolation and depression) problems [12]. Overestimation of BMI is a known phenomenon [13]. This study shows that overestimation of body weight is much lower (26.76\%) than in a group of women tested by Wong (51.4\%) [14]. Among those who incorrectly self-recorded their BMI, 91.18\% are female students of Gdansk University of Physical Education and Sport who practiced or practice sport (Table 3). Probably not without significance is the type of college they study at. Higher sports level is often associated with a slim figure and a low percentage of fatty tissue, which disrupts selfassessment. Results of logistic regression confirm previous suppositions (Table 4, Fig. 1). The more the figure fits into the fashion figure as mass media idea of perfection (lower body weight and BMI), the higher the chance for correct self-recorded BMI. The observed increase in the probability of proper self-assessment together with increasing father's education may be associated with a higher level of general knowledge about health passed on to children in everyday life (Table 4). Why were such dependencies not noted in mothers? Maybe a higher role of the father in bringing up children is one of the reasons. An attempt to explain it will be made in further studies. 
Undoubtedly, the causes of inadequate to reality self-recorded BMI are complex. The time of turning from adolescence to adulthood brings huge changes of the physical (changes in the composition and proportions of the body) and mental nature (formation of a new body image, and as a consequence one's own identity). These extremely turbulent changes take place in the background of commonly prevailing and promoted by mass media idea of "thinner is better". Thus the assessment of one's own body is mostly made by comparing it to generally accepted ideal of a woman - a slim figure $[12,15,16]$. As pointed out by Rovia [17], young people do not have enough knowledge about their body weight appropriate for their age and height. Probably, this is another reason for inadequate self-recorded BMI in the group of women; however, an increase in the probability of a proper BMI self-assessment in the subsequent research year is optimistic (Table 4, Fig. 1). The study is ongoing, which will confirm or verify the results.

\section{CONCLUSIONS}

As the results demonstrate, the BMI evaluation cannot be based only on information obtained from self-assessment made by young women. Very often, they do not have such a skill, mainly those who practiced or still practice sport. Far from reality self-assessment means a strong possibility of improper nutrition, which may result in serious health consequences.

Preventing such a behavior should be an important part of health education, especially among the young. There is, therefore, a need to teach children, young people and their guardians regular and objective methods of their body weight evaluation. Nurses who perform screening, coaches during a routine examination of body weight and height, and teachers should play a huge role in these activities.

\section{REFERENCES}

[1] Pi-Suyner FX. The obesity epidemic pathophysiology and consequences of obesity. Obes Res. 2002;10(suppl.):97-104.

[2] Kinalska I, Popławska-Kita A, Telejko B, Kinalski M, Bonenberg A. Otyłość a zaburzenia przemiany węglowodanowej [Obesity and carbohydrate metabolism]. Endokrynologia, Otyłość, Zaburzenia Przemiany Materii. 2006;2(3):94-101. Polish.

[3] Wójtowicz E. Występowanie chorób sercowo-naczyniowych wśród rodziców studentów i studentek I roku studiów dziennych Akademii Wychowania Fizycznego i Sportu w Gdańsku [Incidence of cardiovascular diseases in the parents of the first-year daily students at the Gdansk University of Physical Education and Sport]. Annales Universitatis Mariae Curie-Sklodowska. 2004;LIX,suppl.XIV,565, Sectio D:435-440. Polish.

[4] Wójtowicz E. Gender, age, body weight, BMI, physical activity of adults and probability of the appearance of chronic diseases. In: Mosiewicz J, editor. Risk factors and prevention in a fight for health and wellness. Lublin: Wydawnictwo Neurocentrum, XXXVII; 2008, 337-344.

[5] Jaśko J, Kamecka-Krupa J. Czynniki ryzyka anoreksji [Anorexia risk factors]. Probl Hig Epidemiol. 2007;88(3):254-258. Polish.

[6] Cachelin FM, Rebeck RM, Chung GH, Pelayo E. Does ethnicity influence body-size preference? A comparison of body image and body size. Obes Res. 2002;10(3):158-166.

[7] Melosik Z. Tyrania szczupłego ciała i jej konsekwencje [The slim body tyranny and its consequences]. In Melosik Z, editor. Ciało i zdrowie w społeczeństwie konsumpcji [Body and health in a consummerist society]. Toruń-Poznań: Edytor; 1999, 139-158. Polish.

[8] Stoke R, Recascino CH. Women's perceived body image: relations with personal happiness. J Women Aging. 2003;15(1):17-29.

[9] Bąk-Sosnowska M, Mandal S, Zachorska-Markiewicz B. Związek nieadekwatnego wyobrażenia własnego ciała $\mathrm{z}$ nadwagą u kobiet [Relation between non adequate imaginary picture of personal body and the overweight at women]. Ann Acad Med Siles. 2006;60(5):385-390. Polish.

[10] Boschi V, Siervo M, D’Orsi P, et al. Body composition, eating behavior food-body concerns and eating disorders in adolescent girls. Ann Nutr Metab. 2003;47(6):284-293. 
[11] WHO. Global database on Body Mass Index: BMI classification, http://apps.who.int/bmi/index.jsp?introPage=into_3.html [accessed 18.11.2010]

[12] Kołoło H, Woynarowska B. Self-perception of body mass and dieting in adolescents. Przegl Pediatr. 2004;34(3/4):196-201.

[13] Wójtowicz E. Body mass index in female first-year students of full-time studies at the Academy of Physical Education and Sport in Gdansk: reality, self-evaluation, dreams. Balt J Health Phys Activ. 2011;3(1):44-54.

[14] Wong Y, Huang YC. Obesity concerns, weight satisfaction and characteristics of female dieters: a study on female Taiwanese college students. J Am Coll Nutr .1999;18(2):194-200.

[15] Jestes D. Body image: how you see it, how you don't. http://www.clearinghouse.mwsc.edu/manuscripts/93.asp [accessed 12.04.1994].

[16] Abraham SF. Dieting, body weight, body image and self-esteem in young women: doctor's dilemmas. Med J Aust. 2003;178(12):607-611.

[17] Rovia RF, Pons IF, Martinez MI, Sánchez RR. Self-reported versus measured height, weight and body mass index in Spanish Mediterranean teenagers: Effect of gender, age and weight on perceptual measures of body image. Ann Nutr Metab. 2002;46:68-72. 